\title{
EXPLORING ENVIRONMENTAL DETERMINANTS OF THE GEOGRAPHIC DISTRIBUTION OF BROOMRAPE (Orobanche cumana Wallr.)
}

Miladinović, D. ${ }^{1}$, Cantamutto, M..$^{2^{*}}$, Vasin, J. $^{1}$, Dedić, B. ${ }^{1}$, Alvarez, D. ${ }^{3}$, Poverene, M. ${ }^{2}$

${ }^{1}$ Institute of Field and Vegetable Crops, Maksima Gorkog 30, 21000 Novi Sad, Serbia

${ }^{2}$ Departamento de Agronomía, Universidad Nacional del Sur, 8000, Bahía Blanca Argentina

${ }^{3}$ Instituto Nacional de Tecnología Agropecuaria, Manfredi Argentina

Received: November 15, 2011

Accepted: June 10, 2012

\section{SUMMARY}

Broomrape is one of the most critical biotic constraints to sunflower crop production. In the most extended sunflower crop area of the world, distributed across Black sea region, this parasitic weed shows a high occurrence. The weed, originally from the Caucasus region, has progressively migrated to the South of the Eurasia continent. The actual invaded area reaches Spain, Israel, Kazakhstan, China, Mongolia and Iran. Due to the usual seed exchange between macro-regions it is not clear why this weed is absent in other extended sunflower crop area located in South America. It is possible that the invasive process could be limited by abiotic restrictions. With the aim to estimate the influence of environmental factors on the actual broomrape geographic distribution, we evaluated 14 sunflower habitats of Serbia with different levels of natural infection and nine natural habitats of wild sunflower in Argentina. The altitude, latitude, longitude, mean hottest month temperature, mean coolest month temperature, and average rainfall of 10 habitats from Serbia showed no differences between infected and non-infected soils. The natural initial infection of four soils from Serbia did not influence the Orobanche attack intensity in a greenhouse experiment with artificial inoculation. Soil texture, total N, humus and calcareous content, as well as $\mathrm{pH}$, had no effect on Orobanche attack intensity. In the greenhouse experiment, Principal Components Analysis showed that Orobanche attack intensity (expressed as parasite plant number per sunflower plant) was inversely associated only with $\mathrm{P}$ availability (AL$\mathrm{P}_{2} \mathrm{O}_{5}$ ), but the linear relationship between both variables was not significant. When Argentinean habitats were included in the database, strong differences between invaded and not invaded areas were found regarding geographic localization, as expected. The invaded habitats differed by the coolest month mean temperature, but no significant differences were found for the remaining climatic parameters. Soil fertility and the texture of 13 soils with different natural Orobanche infection showed no differences between invaded and non-invaded

* Corresponding author: e-mail: mcantamutto@yahoo.com 


\begin{abstract}
habitats. A better understanding of the abiotic determinants of Orobanche geographic distribution could help to design management tools to prevent the continuous increase of the invaded area and to limit damage to sunflower in the regions presently affected by the weed.
\end{abstract}

\title{
Key words: broomrape, climate, geographic distribution, soil composition, sunflower
}

\section{INTRODUCTION}

The broomrape family Orobanchaceae comprises more than a hundred parasitic plant species predominantly (about 90\%) native to temperate zones of the Old World (Mitich, 2011). As the economic losses caused by this family are high, several strategies have been developed with the aim to limit its impact on different crop hosts. Breeding for resistance is the most economically and environmentally friendly method for broomrape (Orobanche sp.) control.

In sunflower, several efforts have been made to develop varieties resistant to the specific parasite $O$. cumana. The genetic improvement was initiated in Russia at the beginning of the last century by Dr. V.S. Pustovoit. Since then, the durability of any resistance source has been short due to the continuous emergence of new virulent races (Fernandez-Martínez et al., 2010). Though it is also possible to use chemical control options (Eizenberg et al., 2006), the integrated control strategies are recommended (Rubiales et al., 2009).

Broomrape does not always show a uniform geographical distribution in the invaded areas (Gonzáles-Andújar et al., 2001). The sunflower parasitic weed $O$. cumana is absent in several important sunflower cultivation areas in North and South America. Due to the small seed size, the intentional or non-intentional introduction of this parasitic weed cannot be rejected, considering the intense international trade, ussually associated with plant invasions (Nuñez and Pauchard, 2010). Perhaps broomrape falls in the $90 \%$ of plants that fail to invade a new ecosystem because of limitations imposed by biotic and abiotic habitat components (Kolar and Lodge, 2001).

Temperature is one important abiotic factor that controls broomrape development. Soil temperature fluctuations during a warm wet period are required for the activation of germination hormones (Song et al., 2005). Only after this preconditioning process, the root host stimulant exudates can induce seed germination. Once germination is induced, the development of $O$. cumana on sunflower is a highly temperature-dependent process (Ephrath and Eizenberg, 2010).

Some soil factors could explain the success of a plant invasion (McGone et al., 2011). Soil biota can limit plant invasions favouring the pre-existent plant community (Reinhart and Callaway, 2006). Soil texture can also influence the vegetation structure (Dodd et al., 2002). Broomrape generally occurs on sandy soils where nitrogen availability is poor (Dhanapal et al., 1996). It was also found that soil 
salinity could limit the incidence of the $O$. cernua attack on tomato plants (Al-Khateeb et al., 2005).

To elucidate the mechanisms related to successful plant invasions, it is necessary to investigate according to several biogeographical scales (Hierro et al., 2005). The distribution of a plant species is affected by the processes operating at multiple environmental and ecological scales (Jones, 2011). The habitat suitability for a plant invader could be estimated by biotic and abiotic habitat variables (Radosevich et al., 2005). A comparative work between occupied and endangered habitats could give important insights for prediction of plant invasions.

The objective of this study was to explore the dissimilarity between the soils from Serbia and Argentina invaded and non-invaded by broomrape, as well as the differences in the climatic and geographic parameters between broomrape invaded and non-invaded sites in these two countries.

\section{MATERIALS AND METHODS}

The exploratory study was performed on three main geographic scales. The influence of habitat climatic and geographic parameters on broomrape distribution in Serbia was investigated. The data comprise latitude, longitude, altitude, mean hottest month temperature, mean coolest month temperature and average annual rainfall of ten experimental fields for sunflower experimental evaluation in the Institute of Field and Vegetable Crops. The environmental parameters between the infested and non-infested soils were compared by the Kruskal-Wallis non-parametric test.

The influence of habitat micro-abiotic parameters of Serbia was explored in a greenhouse experiment. Soil samples $(30 \mathrm{~cm}$ depth) from four sites, broomrape infested and non-infested were used in the experiment. Following soil physical and chemical characters were determined: $\mathrm{pH} ; \mathrm{CaCO}_{3}=$ calcareous content; $\mathrm{Nt}$; $\mathrm{AL} \mathrm{P}$; $\mathrm{AL} \mathrm{K}$, as well as soil texture. Soil $\mathrm{pH}$ value was determined potentiometrically, both in soil suspension with potassium chloride $(\mathrm{pH} \mathrm{KCl})$ and in water $\left(\mathrm{pH} \mathrm{H}_{2} \mathrm{O}\right)$. Content of $\mathrm{CaCO}_{3}$ was determined volumetrically using Scheibler's calcimeter (\%), while total nitrogen (Nt) was determined with a CHNS analyzer (\%). Humus content was measured according to Tjurin, while available $\mathrm{P}_{2} \mathrm{O}_{5}$ (AL P) content and available $\mathrm{K}_{2} \mathrm{O}(\mathrm{AL} \mathrm{K})$ were determined by extraction with ammonium lactate. Soil texture (particle size composition) was determined by international B pipette method with the preparation in sodium pyrophosphate (CoSand = coarse sand $(2-0.2 \mathrm{~mm}) \%$; FinSand $=$ fine sand $(0.2-0.02 \mathrm{~mm}) \%$; Silt = lime $(0.02-0.002 \mathrm{~mm}) \%$; Clay = clay $(<0.002 \mathrm{~mm}) \%)$.

Two pots were filled with soil from each site. Total of $70 \mathrm{mg}$ per pot of Orobanche seed, race E, was added into the soil before sowing the susceptible sunflower line $\mathrm{AD}-66$. The plants were grown in a greenhouse at $25^{\circ} \mathrm{C}$ and $16: 8 \mathrm{~h}$ photoperiod. The Orobanche attack intensity was estimated six weeks after sowing as 
the number of weed plants per sunflower plant. The results were analysed with ANOVA and Newman-Keuls post-hoc test. The effect of soil composition on broomrape occurrence in the greenhouse experiment was investigated by principal component analysis and linear regression.

To explore the dissimilarity between European and South American sites, the habitats of nine wild Helianthus annuus stable populations from Argentina (Orobanche free) were compared with the invaded and non-invaded sites from Serbia. The experimental procedure to collect the abiotic parameters of the Argentine sites was described in Cantamutto et al. (2008). These habitats could be considered as the highest risk places for broomrape invasion in Argentina, because wild Helianthus populations have been established in the same soils for at least 10 years (author's observation). The dissimilarity of geographic, climatic, and micro-abiotic parameters was performed by Kuskal-Wallis non-parametric test.

\section{RESULTS AND DISCUSSION}

At the geographical level there were no differences between broomrape invaded and non-invaded habitats from Serbia (Table 1). Under this macro-abiotic scale, the observation implies that the broomrape free habitats might be invaded by the parasitic weed.

Table 1: Characterization of 10 sunflower crop growing habitats of Serbia with two levels of Orobanche infestation. Kruskal-Wallis non-parametric test showed no differences between both groups.

\begin{tabular}{lcc}
\hline \multirow{2}{*}{ Environmental parameter } & \multicolumn{2}{c}{ Orobanche natrl. infestation } \\
\cline { 2 - 3 } & NO $(\mathrm{n}=5)$ & YES $(\mathrm{n}=5)$ \\
& Mean $\pm \mathrm{SD}$ & Mean $\pm \mathrm{SD}$ \\
\hline Latitude $\left({ }^{\circ} \mathrm{N}\right)$ & $44.92 \pm 0.98$ & $45.33 \pm 0.71$ \\
Longitude $\left({ }^{\circ} \mathrm{E}\right)$ & $20.78 \pm 1.38$ & $20.27 \pm 1.34$ \\
Altitude $($ mosl) & $96 \pm 24$ & $89 \pm 10$ \\
Mean hottest month temperature $\left({ }^{\circ} \mathrm{C}\right)$ & $27.4 \pm 0.4$ & $27.4 \pm 0.6$ \\
Mean coolest month temperature $\left({ }^{\circ} \mathrm{C}\right)$ & $-4.1 \pm 1.1$ & $-4.5 \pm 0.3$ \\
Annual rainfall $(\mathrm{mm})$ & $616 \pm 54$ & $579 \pm 40$ \\
\hline
\end{tabular}

Table 2: Orobanche intensity attack (weed plants/sunflower plant) following artificial inoculation of four soils $(0-30 \mathrm{~cm})$ with different natural infections. ANOVA showed significant $(\mathrm{p}<0.05)$ site effect. Means with different letters differenced according to Newman-Keuls test $(\mathrm{p}<0.05)$.

\begin{tabular}{lcc}
\hline Site & Natural infection & Attack intensity \\
\hline Kula & Heavy & $2.61 \mathrm{a}$ \\
Vrbas & Heavy & $4.44 \mathrm{ab}$ \\
Subotica & Moderate & $4.53 \mathrm{ab}$ \\
Novi Sad & Free & $6.36 \mathrm{~b}$ \\
\hline
\end{tabular}


If at macro-environmental scale there are no differences, it is likely that some biotic soil parameters impose a limitation to the weed development. This could not be demonstrated by the greenhouse experiment where the natural broomrape infection was unrelated to the attack degree under controlled seed infection (Table 2). The highest broomrape attack was observed in the naturally broomrape free soil from Novi Sad. However, a heavy natural infested soil from Kula had the lower broomrape attack, but in all cases the attack severity level on the susceptible sunflower AD-66 was high enough to limit crop production. Under these findings, the hypothesis about soil biotic antagonists as controllers of the weed invasion was difficult to sustain.

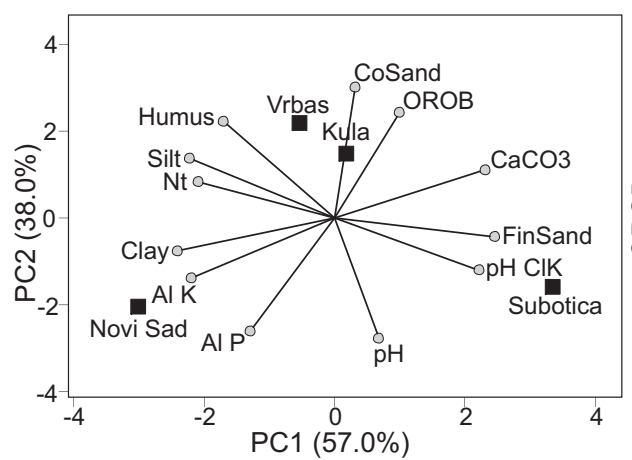

Figure 1: Principal components analysis of micro-abiotic soil parameters and Orobanche intensity attack (OROB) following controlled inoculation in a greenhouse experiment.

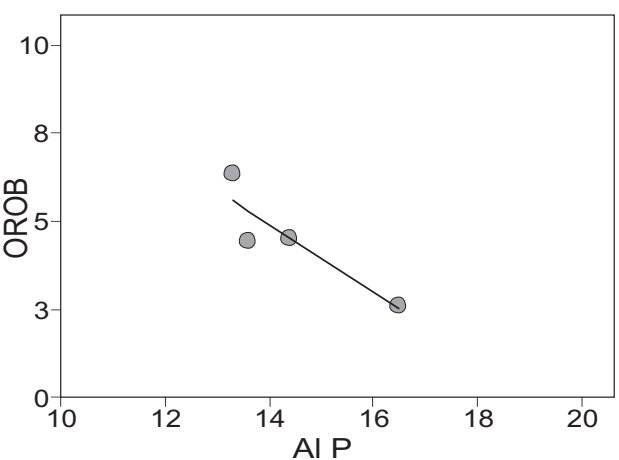

Figure 2: Linear correlation $\left(R^{2}=0.81\right.$; $p=0.1006$ ) between phosphorus availability ( $\mathrm{Al} \mathrm{P}=\mathrm{AL}-\mathrm{P}_{2} \mathrm{O}_{5} \mathrm{mg}$ / $100 \mathrm{~g}$ ) and Orobanche intensity attack $(O R O B=$ weed plants/sunflower plant) following controlled inoculation of four soils

Soil texture could have impact on the parasitic weed virulence. The increased coarse sand content was positively associated with Orobanche attack intensity under greenhouse conditions (Figure 1). Soil available P was also correlated with the attack, but in a negative way. This association was also demonstrated by the negative linear relationship between $P$ availability and Orobanche attack (Figure 2). There is no available bibliography about this macro-nutrient effect on broomrape epidemiology. The only data available are on negative influence of other macronutrient, nitrogen, on germination of broomrape seed of several Orobanche species (Westwood and Foy, 1999). In general, mineral nutrition improvement impacts on plant health and a balanced fertilization could be used as a technological tool to limit the broomrape damage (Dhanapal et al., 1996). Manure and fertilizer applications also induce micro-environmental changes at root levels, as acidity increases, which could limit the host-parasite interaction, particularly at the infection phase (Al-Khateeb et al., 2005). 
Including the weed free soils of established wild $H$. annuus populations in Argentina, differences on geographic localization between Orobanche invaded and non-invaded areas were found, as expected (Table 3). Higher altitudes were observed in non-invaded habitats, though the altitude of both environmental groups was not different. Latitude seems to have an indirect effect on the photoperiod during sunflower crop development. This effect was not addressed in this explorative work, as there is not strong evidence about its influence since broomrape seed germinates in deep soil layers, without light influence. Regarding climatic parameters, the broomrape invaded habitats differed from the free ones only by the mean coolest month temperature, with the sites where Orobanche is present being cooler. As the coolest month temperature could have an influence on seed conditioning (Song et al., 2005), the mild low temperatures during winter could explain the Orobanche absence in Argentina. To be conclusive in this aspect, it would be necessary to study some other invaded habitats located at lower latitudes of Spain and Israel, with mild winters.

Table 3: Environmental characterization of 10 sunflower habitats of Serbia with two levels of Orobanche infection and nine wild sunflower habitats of Argentina. Kruskall-Wallis non-parametric test showed: $\mathrm{ns}=$ no differences; ${ }^{*}=$ differences at $\mathrm{p}<0.05$ and ${ }^{* *}$ differences at $\mathrm{p}<0.01$ between groups.

\begin{tabular}{lcc}
\hline \multirow{3}{*}{ Environmental parameter } & \multicolumn{2}{c}{ Orobanche natural infection } \\
\cline { 2 - 3 } & $\mathrm{NO}(\mathrm{n}=14)$ & YES $(\mathrm{n}=5)$ \\
& Mean $\pm \mathrm{SD}$ & Mean $\pm \mathrm{SD}$ \\
\hline Latitude $\left({ }^{\circ} \mathrm{N}\right)$ & $37.20 \pm 0.50$ & $45.33 \pm 0.71^{\star *}$ \\
Longitude $\left({ }^{\circ} \mathrm{E}\right.$ or $\left.\mathrm{W}\right)$ & $53.45 \pm 19.83$ & $20.27 \pm 1.34{ }^{* *}$ \\
Altitude $(\mathrm{mosl})$ & $224 \pm 189$ & $89 \pm 10 \mathrm{~ns}$ \\
Mean hottest month temp. $\left({ }^{\circ} \mathrm{C}\right)$ & $25.4 \pm 1.8$ & $27.4 \pm 0.6 \mathrm{~ns}$ \\
Mean coolest month temp. $\left({ }^{\circ} \mathrm{C}\right)$ & $-3.8 \pm 6.2$ & $-4.5 \pm 0.3$ * \\
Annual rainfall $(\mathrm{mm})$ & $600 \pm 206$ & $579 \pm 40 \mathrm{~ns}$ \\
\hline
\end{tabular}

Table 4: Soil characterization in sunflower habitats with two levels of Orobanche natural infection. The without Orobanche group (NO) include nine soils of stable natural wild $H$. annuus populations in Argentina, and one soil from Serbia without Orobanche infection. Kruskall-Wallis non-parametric test showed no differences between both groups.

\begin{tabular}{lcc}
\hline \multirow{2}{*}{ Soil parameters } & \multicolumn{2}{c}{ Orobanche natural infection } \\
\cline { 2 - 3 } & NO $(\mathrm{n}=10)$ & YES $(\mathrm{n}=3)$ \\
Mean \pm SD & Mean \pm SD \\
\hline Fertility & $7.7 \pm 0.8$ & $8.1 \pm 0.1$ \\
$\mathrm{pH}$ & $3.6 \pm 0.9$ & $2.9 \pm 0.6$ \\
Humus (\%) & $28.7 \pm 15.8$ & $14.8 \pm 1.5$ \\
Available P (ppm) & $13.7 \pm 7.4$ & $19.0 \pm 8.1$ \\
\hline Texture (\%) & $30.0 \pm 12.4$ & $25.1 \pm 8.2$ \\
Clay & $56.3 \pm 19.1$ & $55.9 \pm 15.4$ \\
Loam & & \\
Fine Sand &
\end{tabular}


Mollisols and Entisols are the predominant soil taxa in the north part of Serbia (Vojvodina Province) and Argentine, so a complete differentiation between invaded and non-invaded sites should be explained by specific soil parameters. Considering all data, soil chemical composition and texture of Orobanche invaded habitats were not different from weed free sites (Table 4).

In spite of this lack of statistical differences, the $\mathrm{P}$ availability in non-invaded habitats was higher. This fact, together with higher soil organic matter content and higher acidity in non-invaded habitats suggested a general low fertility of invaded habitats.

Considering the intense seed exchange between regions, the lack of seed introductions of this dangerous weed in non-invaded areas in America is difficult to sustain. Several weeds have been introduced in the New World before the development of secure phytosanitary legislation for seed exchange. It seems more likely that some habitat restrictions had limited the Orobanche cumana invasion to sunflower crop areas of America. As the geographic distribution of a given plant species could be explained by biotic and abiotic habitat parameters, it is necessary to continue exploring the migration pattern of this dangerous weed. If the O. cumana invasive process was limited by certain biotic and abiotic habitat constraints (Kolar and Lodge, 2001), their identification could help to develop technological tools to limit the economic losses caused by broomrape in the affected areas. Due to the limited data base explored in this research, it was impossible to be conclusive. With these restrictions, the present explorative work showed that phosphorous fertilization seems to be a candidate technology to limit the weed damage.

\section{ACKNOWLEDGEMENTS}

This work was supported by Ministry of Education and Science, Republic of Serbia, project TR 31025; Instututo Nacional de Tecnología Agropecuaria, Argentina proyecto PNOLE 03105; Agencia Nacional de Promoción de Investigaciones Científicas y Tecnológicas PICT 020, Argentina and Servicio Nacional de Sanidad y Calidad Agroalimentaria, Argentina.

\section{REFERENCES}

Al-Khateeb, W.M., Hameed, K.M. and Shibli, R.A., 2005. Influence of soil salinity on the interaction between tomato and broomrape plant (Orobanche cernua). Plant Pathology Journal 21: 391-394.

Cantamutto, M., Poverene, M. and Peinemann, N., 2008. Multi-scale analysis of two annual Helianthus species naturalization in Argentina. Agriculture, Ecosystems and Environment 123: 69-74.

Dhanapa, G.N., Struik, P.C., Udayakumar, M. and Timmermans, P.C.J.M., 1996. Management of broomrape (Orobanche spp.) - A review. Journal of Agronomy and Crop Science 175: 335-359. 
Dodd, M.B., Lauenroth, WK., Burke, I.C. and Chapman, P.L., 2002. Associations between vegetation patterns and soil texture in the shortgrass steppe. Plan Ecology 158: 127-137.

Eizenberg, H., Colquhoun, J.B. and Mallory-Smith, C.A., 2006. Imazamox application timing for small broomrape (Orobanche minor) control in red clover. Weed Science 54: 923-927.

Ephrath, J.E. and Eizenberg H., 2010. Quantification of the dynamics of Orobanche cumana and Phelipanche aegyptiaca parasitism in confectionary sunflower. Weed Research 50: 140-152.

González-Andújar, J.L., Martínez-Cob, A., López-Granados, F. and García-Torres, L., 2001. Spatial distribution and mapping of crenate broomrape infestations in continuous broad bean cropping. Weed Science 49: 773-779.

Hierro, J.L., Maron, J.L. and Callaway, R.M., 2005. A biogeographical approach to plant invasions: the importance of studying exotics and their introduced and native range. Journal of Ecology 93: 5-15.

Jones, J.P.G., 2011. Monitoring species abundance and distribution at the landscape scale. Journal of Applied Ecology 48: 9-13.

Kolar, C.S. and Lodge, D.M., 2001. Progress in invasion biology: predicting invaders. Trends in Ecology and Evolution 16: 199-204.

McGlone, C.M., Sieg, C.H. and Kolb, T.E., 2011. Invasion resistance and persistence: established plants win, even with disturbance and high propagule pressure. Biological Invasions 13: 291-304.

Mitich, L., 2011. Orobanche: the broomrapes. Intriguing world of weeds. Weed Science Society of America. http://wssa.net/Weeds/ID/WorldOfWeeds.htm\#x (access May 5, 2011)

Nuñez, M.A. and Pauchard, A., 2010. Biological invasions in developing and devcloped countries: does one model fit all? Biological Invasions 12: 707-714.

Radosevich, S.R., Endress, B.A. and Parks, C.G., 2005. Defining a regional approach for invasive plant research and management. In: Invasive Plants: Ecological and Agricultural Aspects. Inderjit Ed. Birkhäuser, Verlag, Basel.

Reinhart, K.O. and Callaway, R.M., 2006. Soil biota and invasive plants. Tansley review. New Phytologist 170: 445-457.

Republic Hydrometeorological Service of Serbia, http://www.hidmet.gov.rs/latin/meteorologija/ klimatologija_godisnjaci.php

Rubiales, D., Verkleij, J., Vurro, M., Murdoch, A.J. and Joel, D.M., 2009. Parasitic plant management in sustainable agriculture. Weed Research 49 (Suppl. 1): 1-5.

Song, W.J., Zhou, W.J., Jin, Z.L., Cao, D.D., Joel, D.M., Takeuchi, Y. and Yoneyama, K., 2005. Germination response of Orobanche seeds subjected to conditioning temperature, water potential and growth regulator treatments. Weed Research 45: 467-476.

Stohlgren, T.J. and Schnase, J.L., 2006. Risk analysis of biological hazards: what we need to know about invasive species. Risk Analysis 26: 163-173.

Westwood, H.J. and Foy, L.C., 1999. Influence of nitrogen on germination and early development of broomrape (Orobanche spp.) Weed Science 47: 2-7.

\title{
EXPLORANDO LOS DETERMINANTES AMBIENTALES DE LA DISTRIBUCIÓN GEOGRÁFICA DEL JOPO (Orobanche cumana Wallr.)
}

\author{
RESUMEN
}

El jopo es una maleza parásita que constituye una de las principales limitantes bióticas de la producción mundial de girasol. Esta maleza presenta una elevada ocurrencia en la extendida región cultivada con girasol en la zona del Mar Negro. Nativa del Cáucaso, la maleza ha migrado progresivamente hacia el sur de Eurasia. Actualmente el área invadida alcanza a España, Israel, Kazakhastan, China, Mongolia e Irán. No está claro porque, a pesar del intenso intercambio de semillas, la maleza está ausente en importantes áreas de girasol de Sud América. Es posible que el proceso invasivo haya estado limitado por restricciones abióticas. Con el propósito de estimar la influencia de factores ambientales sobre la distribución actual del jopo evaluamos 14 hábitats 
de girasol de Serbia con diferentes niveles de infección natural y nueve hábitats de girasol silvestre de Argentina. En 10 hábitats de Serbia no se observaron diferencias entre suelos infectados y libres de la maleza en la latitud, longitud, temperatura media del mes más cálido, temperatura media del mes más frío y promedio anual de lluvias. En un experimento con inoculación artificial en invernadero, la infección natural de cuatro suelos de Serbia no afectó la intensidad de ataque de Orobanche. La textura del suelo, contenido de $\mathrm{N}$, de humus, caliza y el pH no tuvieron efectos sobre la intensidad de ataque de Orobanche. En el experimento de invernadero el Análisis de Componentes Principales mostró que la intensidad de ataque de Orobanche (expresado como el número de plantas parásitas por planta de girasol) estuvo inversamente relacionada con la disponibilidad de $\mathrm{P}\left(\mathrm{AL}-\mathrm{P}_{2} \mathrm{O}_{5}\right)$ pero la regresión linear entre ambas variables no fue significativa. Cuando en la base de datos se incluyeron los hábitats de Argentina, las áreas invadidas se diferenciaron de las libres en aspectos de localización geográfica, como era esperable. Los hábitats invadidos difirieron en la temperatura media del mes más frío, pero no se encontraron diferencias en el resto de las variables climáticas. La fertilidad química y la textura de 13 suelos con diferentes niveles naturales de Orobanche no mostraron diferencias entre áreas invadidas y no invadidas. Una mejora en la comprensión de los determinantes abióticos que modulan la distribución geográfica de Orobanche podría ayudar a diseñar herramientas de manejo para prevenir el continuo incremento del área invadida y limitar el daño al girasol en las regiones actualmente afectadas por la maleza. 
